\title{
Zbigniew Mazur
}

Department of English

Maria Curie-Sklodowska University

\section{The Leisure Pursuits of Gentlewomen in Colonial Virginia: Gender Construction and Male Domination}

Drawing on the studies of women's history in Early America and on the research into play and entertainment in the British North American colonies, the present article discusses the functions of leisure practices in constructing femininity and shaping the patriarchal gender relations among the gentry of eighteenth-century Virginia. In the colonial South it was the elaborate pattern of hospitality and entertainment that produced social space within which young women from the elite were prepared for their future social roles. Male domination was performed in symbolically rich leisure rituals, where both the social roles that men and women played and the objects they used in elaborate practices of public consumption and display of wealth signified the established social order $^{1}$.

Women's history is a well-established research area in the studies of Early America. The first studies devoted to the lives of colonial women were published as early as at the beginning of the $20^{\text {th }}$ century, coinciding with the first wave of feminism. Alice Morse Earle's Colonial Dames and Good Wives and Elizabeth Dexter's Colonial Women of Affairs: Women in Business and the Professions in America before 1776 were the first attempts to present women as important figures in the history of colonial America. Julia Cherry Spruill in Woman's Life and Work in the Southern Colonies offers a pioneering attempt to characterize Southern women as a social group. The early studies, while challenging the dominant vision of history as an account of male accomplishments, mostly analyse the daily lives of white, upper class women ${ }^{2}$.

1 The arguments in this essay are largely based on the present author's wider study of leisure in eighteenth-century Virginia, The Power of Play: Leisure, Recreation and Cultural Hegemony in Colonial Virginia, Lublin 2010.

2 A. M. Earle, Colonial Dames and Good Wives, Boston 1904; E. Dexter, Colonial Women of Affairs: Women in Business and the Professions in America before 1776, New York 1924, reprinted 1972; J. C. Spruill, Woman's Life and Work in the Southern Colonies, Chapel Hill, NC 1938. 
The impact of feminism on American historical writing in the 1970s and the 1980s resulted not only in greater emphasis on the studies of gender relations in the context of social power and inequality, but also in a discovery of new research areas, which could bring to light the reality of women's lives in the family, neighbourhood, and community. New studies in colonial history, for example those by Lois Green Carr, Lorena S. Walsh and Carole Shammas, deal with the microcosms of women's experience, including the lives of poor white and black females, and reconstruct the networks of relationships which shaped women's place in the colonial environment. Characteristically, it was the methods of economic history and the studies of work patterns and material worlds that provided new insights into the women's ordinary lives and pointed to the factors which determined their interactions with men $^{3}$. For example, Laurel Ulrich's book A Midwife's Tale demonstrates the significance of women's work in and outside the household. Ulrich studies the diary of Martha Ballard, a midwife and healer from the Massachusetts frontier, and presents the complex social networks which her protagonist entered. She delineates the complex set of interactions in which women were involved, including marriage and sexual relationships, thus dispelling some earlier simplifications about the nature of gender relations in Early American society ${ }^{4}$.

As far as the history of women in colonial Virginia is concerned, Kathleen Brown's Good Wives, Nasty Wenches, and Anxious Patriarchs still remains the most significant study. Brown goes beyond gender as an analytical category, showing that it is at the intersection of gender, class and race that lives of women, African Americans, Native Americans as well as European Americans, were constructed. In a wide-sweeping and detailed study of a variety of sources, Brown shows how the categories of race and gender were systematically reshaped in Virginia to more efficiently support the patriarchy of the gentry5.

The present article returns to some questions set in the early stages of the development of women's history of the colonial South in general and Virginia in particular. The paper studies the position of women in the colonial elite and analyzes the mechanisms of power relations within this group with reference

3 See for example L. G. Carr and L. S. Walsh, "The Planter's Wife: The Experience of White Women in Seventeenth-Century Maryland," William and Mary Quarterly, vol. 34 (1977), pp. 54271 and C. Shammas, "Black Women's Work and the Evolution of Plantation Society in Virginia," Labor History, vol. 26 (1985), pp. 5-28.

4 L. T. Ulrich, A Midwife's Tale: The Life of Martha Ballard, Based on Her Diary, 1785-1812, New York 1990.

5 K. M. Brown, Good Wives, Nasty Wenches, and Anxious Patriarchs: Gender, Race, and Power in Colonial Virginia, Chapel Hill, NC 1996. For a review of recent work in women's history in Early America see for example T. Snyder, "Refiguring Women in Early American History," William and Mary Quarterly, vol. 69 (2012), pp. 421-450. 
to the outwardly non-politicized area of leisure activities. Such issues are addressed in the work of Linda L. Sturtz, and Cynthia Kierner, who discuss, among other aspects of eighteenth-century women's history, the relationships between female pastimes, elite hospitability, and patriarchy in early Virginia ${ }^{6}$. As male domination is redefined today in terms of concrete relationships and interactions shaping women's life rather than treated as a general, abstract category, these issues seem to be a relevant topic for discussion, especially as the life of the Virginia gentry has been thoroughly researched and reinterpreted from the perspectives of political and economic relations both within in the colony and in a wider Atlantic context.

The Virginia gentry was a small group of colonists who, in the early decades of the eighteenth century, created a ruling elite, taking advantage of their economic success in the cultivation and trade of tobacco and in acquisition of land. The elite, strengthened by ties of kinship and intermarriage, shared the style of living and ideas of social hierarchy. By the middle of the eighteenth century, they were a solid, interconnected group, sharing a gentry identity, though not completely confident of its own rank, because of the fact that most of heads of their families were gentlemen only of the second or third generation?

Identifiable by their wealth, the gentry symbolically displayed their affluence to indicate high social status, but wealth was only the first factor which brought with itself the right to rule. The colonial society resorted to the category of gentility in defining high social rank. The aspirations to power had to be legitimised by proper cultural refinement, righteousness, and moral virtues. Consequently, the Virginia gentry felt obligated to accumulate appropriate cul-

${ }^{6}$ L. L. Sturtz, "Within Her Power:" Propertied Women in Colonial Virginia, New York 2002, and "The Ladies and the Lottery: Elite Gambling in Eighteenth-Century Virginia," Virginia Magazine of History and Biography, vol. 104 (1996), pp. 165-184; C. A. Kierner, "Genteel Balls and Republican Parades: Gender and Early Southern Civic Rituals, 1677-1826," Virginia Magazine of History and Biography, vol. 104 (1996), pp. 184-210, and "Hospitality, Sociability, and Gender in the Southern Colonies," Journal of Southern History, vol. 53 (1996), pp. 449-480.

7 For analyses of the gentry as a social class see for example C. S. Sydnor, Gentlemen Freeholders: Political Practices in Washington's Virginia, Chapel Hill, NC 1952; B. Bailyn, "Politics and Social Structure in Virginia," Seventeenth-Century America: Essays in Colonial History, ed. J. M. Smith, Charlottesville, VA 1959, pp. 90-116; L. B. Wright, The First Gentlemen of Virginia: Intellectual Qualities of the Early Colonial Ruling Class, Charlottesville, VA 1964; J. P. Greene, "Society, Ideology and Politics: An Analysis of the Political Culture of MidEighteenth-Century Virginia," in Society, Freedom and Conscience: The American Revolution in Virginia, Massachusetts, and New York, ed. R. M. Jellison, New York 1976; C. Shammas, "English Born and Creole Elites in Turn-of-the-Century Virginia," in The Chesapeake in the Seventeenth Century: Essays on Anglo-American Society, eds. T. W. Tate and D. L. Ammerman, Chapel Hill, NC 1979, pp. 274-296; M. Rozbicki, The Complete Colonial Gentleman, Charlottesville, VA 1998; T. H. Breen, Tobacco Culture: The Mentality of the Great Tidewater Planters on the Eve of Revolution, Princeton, N.J. 1985. 
tural capital, whose sources could be found in Europe, with London remaining the centre of good taste and genteel models of behaviour. For the colonial gentry, the most effective course of action which could possibly transform them into a refined elite was to follow the example of the English gentry in their social life and to acquire goods that would manifest knowledge of the most recent European taste. The gentlemen had to display their new cultural capital in social rituals and leisure practices were the best platform for such performance of gentility ${ }^{8}$.

The concept of "leisure" emerged in Britain at the turn of the eighteenth century, when gentlemen and richer members of the middle-class, freed from the necessity of labour, applied such a designation to their management duties, defined as necessary and productive endeavours and not work. As the concept of leisure was growing, its meaning was extended to refer to time spent on other practices of a beneficial and enlightening character. Consequently, book reading, dancing, music, sports, and other forms of entertainment which were useful and educating became leisure activities. Leisure was not just "free time;" the refined elite was supposed to make proper uses of the opportunities that the lack of the necessity to work brought with itself. In Virginia, the growing planter elite enthusiastically embraced the concept of leisure, as they could build a distinctive identity around it. The most prosperous colonists owned the resources which allowed them to designate most of their time as leisure, and this marked them clearly as a privileged group, different from the rest of colonial society 9 .

In colonial Virginia, the appropriate choice of entertainment was not just a matter of choice. The group interest of the gentry required an imposition of a "leisure regime" on its members. As the planter elite aspired to display their genteel status, they sought to fill the free time in their lives with tasteful, educating, and pleasurable activities closest to the pastimes of the English elite. A gentleman was required to make an appearance of being always at leisure, even if the plantation management occupied much of his time and consumed his energy. Even though a Virginia planter might find the convivial atmosphere of a drunk male party appealing, to prove that he was a gentleman he was expected to be engaged in virtuous projects, educating pastimes and polite diversions.

Leisure practices and conspicuous consumption confirmed one's gentility. Consumption was an art, practiced only by the people at the top of society. Those who knew how to consume properly were deemed as people of high

8 Greene, op. cit., pp. 16-17, 37-43. Rozbicki, op. cit., presents a convincing interpretation of the process of the adoption of gentility by the Southern gentry as a way of legitimising their power. R. Bushman in The Refinement of America: Persons, Houses, Cities, New York 1992, offers a detailed description of how the American gentry adopted British fashions and refined styles of living.

9 N. L. Struna, People of Prowess: Sport, Leisure, and Labor in Early Anglo-America, Urbana - Chicago 1996, pp. 166-170. 
rank. High status was displayed in such leisure activities as dinners, balls and other social assemblies, tea drinking, walks and outings, theatre-going, attending lectures, and literary readings. Gentry leisure was to manifest such features of gentility as order, decorum, moderation, and civility ${ }^{10}$.

With patriarchy creating the model of social order, the dominant social categories in colonial Virginia referred to men and defined society in terms of appropriate masculine divisions. Femininity was defined in relation to what it meant to be a man, and more precisely, what it meant to be a male member of a particular social class. Leisure practices, just as many other social activities, helped to build the group identity of the gentlemen as a dominant group, and strengthened their patriarchal hegemony, in terms of domination over other social groups and over women. Thus, in the sphere of leisure the differences between male and female diversions and the roles assigned to women worked both as a mechanism of gender construction and as a tool for creating and maintaining inequality ${ }^{11}$.

Women did not experience leisure in the same way as men. Gentlewomen were not supposed to do manual work, but they had numerous household and family duties, such as planning and overseeing the cooking and other domestic chores done by servants and slaves. Thus, it was women's responsibility to perform the activities that made home leisure possible for the whole family. "Unengaged" time was less frequently available to women than to men of the upper rank. Another factor which largely limited leisure opportunities of the upper-class women was the sparse settlement pattern of the colony. As most Virginians lived on plantations, distant from one another, and as women travelled less frequently than men, female pastimes were largely family-centred and selfmade: card-playing, singing, or dancing. Andrew Burnaby, an English traveller in the colony in 1759 and 1760, argued that the Virginia ladies, except for dancing and "now and then going upon a party of pleasure into the woods to partake of a barbecue, chiefly [spent] their time in sewing and taking care of their families: they seldom read, or endeavour[ed] to improve their minds" 12 .

10 Struna, op. cit., pp. 166-170. The question of what pastimes are appropriate for people of rank in their free time was addressed by the colonial press, compare "Entertainment," Virginia Gazette (hereafter cited as $V G$ ), Dec. 29, 1752, "Eulogy on Early Rising," VG, Dec. 8, 1752, 1, "Entertainment," $V G$, Jan. 24, 1752.

11 See C. Kierner's discussion of gender roles in southern leisure and hospitality in "Hospitality, Sociability, and Gender...”, pp. 449-480.

12 A. Burnaby, Burnaby's Travels through North America, ed. Rufus Rockwell Wilson, 1798, rpt. New York 1904, p. 57. See also M. de Chastellux, Travels in America in the Years 1780-17811782, New York 1827, vol. 2, pp. 384, 426, and 441 for similar descriptions from the period of the Early Republic. The domestic life of Virginia gentry is discussed, for example, by E. Morgan, Virginians at Home: Family Life in the Eighteenth Century, Williamsburg, VA 1952. 
Most women's leisure was set in the domestic environment and happened as part of the practices of family hospitality, an essential form of the organization of social life in the social and geographical environment of Virginia. Women's domestic leisure, often associated with the practice of paying visits and receiving guests was to express the chief ideals of femininity: domesticity, politeness, order, modesty and timidity, good taste, propriety, self-control and similar values. There were restrictions on the forms of play in which such feminine values could be compromised. Women were, for example, barred from most sports and physical exercise. Most forms of competition were reserved for men, as competitiveness was an attribute of masculinity. Women rarely competed in games of skill; instead they were expected to serve as spectators and supporters at contests among men ${ }^{13}$.

Gentlewomen were limited in their choice of leisure practices. Leisure rituals, however, constituted at the same time rare forms of public life in which women were invited to participate. While gentlemen had numerous social opportunities to interact with one another, the ladies found balls, tea-drinking, theatre, parades, horse races, and other the attractions of the "Publick Times" (the periods when the courts were in session in Williamsburg and visitors from all over Virginia came to spend some time in the colonial capital) and official holidays as singular opportunities for more intense social contact. Even though public life, in general, was a sphere where male superiority was manifested (only men engaged in business and politics), women found multiple pleasures in participation in the entertainments accompanying male transactions, and enjoyed chances for less-controlled interactions and opportunities for self-expression, even if only within the limits of the culture of gentility.

Many visitors to the colony, in the mode characteristic for eighteenth-century travellers, felt obliged to assess the gentility of the ladies of eighteenth-century America. The aesthetic categories were used by Burnaby in his - fairly critical - assessment of elite women from Virginia. Burnaby wrote:

The women are, generally speaking, handsome, though not to be compared with our fair countrywomen in England. They have but few advantages, and consequently are seldom accomplished; this makes them reserved, and unequal to any interesting or refined conversation. They are immoderately fond of dancing, and indeed it is almost the only amusement they partake of: but even in this they discover want of taste and elegance, and seldom appear with that gracefulness and ease, which these movements are calculated to display ${ }^{14}$.

13 Struna, People of Prowess, 173 and "Gender and Sporting Practice in Early America." Journal of Sport History, 18 (1991), 10-31.

14 Burnaby, op. cit., 57. L. von Closen, The Revolutionary Journal of Baron Ludwig Von Closen, 1780-1783, ed. E. M. Acomb, Chapel Hill, NC 1958, pp. 166, 181, 185-186, 197. Marquis de Chastellux believed that op. cit., vol. 2, p. 220. 
Ludwig von Closen, aide-de-camp to General Rochambeau during the War of American Independence, considered Virginia elite women "not very pretty," but many of them were "well-bred society," "witty," "amusing," and "lively company." Marquis de Chastellux, another military officer who served in the French expeditionary forces, believed that "in America, music, drawing, public reading, and the work of the ladies, [were] resources as yet unknown." Women, like houses or horses owned by gentlemen, were not expected to have a subjectivity, but rather to live up to - in their dancing, mode of dressing, and conversations - the wealth and status of their husbands or fathers ${ }^{15}$.

This required a close familiarity with the standards of gentility established for and by the English elite. Virginia gentlewomen had to be in touch with the London fashions of the day, to follow the news from the court and the aristocratic houses, to recognize the changes in taste. Not to appear backward or oldfashioned was a difficult task, bearing in mind the distance between the colony and the mother country, the slow flow of information, and the limited resources of the colonists. Despite these obstacles the eighteenth century is the time of intensive importation of all sorts of luxury goods from Britain to America. ${ }^{16}$ Information about metropolitan trends was obtained through correspondence, oral communication, including gossip, and - increasingly - from colonial newspapers. In 1773, just before the revolutionary spirit blew away the colonial ambitions to copy the British models, the following note about the changes in London's hairstyles and fashions for ladies appeared in the Virginia Gazette:

The Toupees are apparently decreasing, and Jewels partly supply the Place of Front Curls; the back part of the Head en chenouille, with the Side Curls pretty much the same; the Height of Stays on a Par, with sharp pointed Peaks; the Projection in Front rather on the Increase; Stomachers, three Rows of Plaits upwards; a single Breastknot and Sleeveknots of the same Silk; triple Flounces to the Sleeves, twelve, nine, and five Inches; triple Ruffles on the Outside, eighteen, fifteen, and eleven Inches; Inside, six, four, and two Inches.

On the petticoat of the Negligee a Frill comes all around, plaited next the Tail; six Inches above that is a Flounce a Quarter of a Yard deep only in the Front; close over that is another Frill as on the Bottom, all of the same Silk; Trains nine Inches and a Half; full Dress as usual, with larger Trains ${ }^{17}$.

The detailed nature of the information suggests that the female readers were expected to be concerned about their physical appearance and familiar with even

15 Kierner, "Genteel Balls and Republican Parades...," p. 190.

16 For a discussion of the consumer revolution in America see for example T. H. Breen, " "Baubles of Britain': The American and Consumer Revolutions of the Eighteenth Century," in Diversity and Unity in Early America, ed. P. D. Morgan, London and New York 1993, pp. 227-256.

17 VG (Purdie and Dixon), February 11, 1773, 1. 
minute modifications of the current vogue. For Virginia ladies of leisure keeping up with the standards of gentility set by the English upper-class was nigh impossible, as suggested by the following fragment from the same article, listing the daily routines of the English aristocracy:

\section{Hours of Employment for both Ladies and Gentlemen.}

Rising Hour, eleven; Breakfast, from that till one; Visiting, and Lounging, from one till free; from three till four, Dressing; Dinner, four to Five; Evening Visits, from seven to eight, Length of Ditto, five Minutes (except on Assignation); publick Places, from eleven to three, as you like it; Bed Time, three in the Morning ${ }^{18}$.

The framework for the construction of the proper gender roles is well manifested by the expectations of the skills which young women were supposed to learn at home and acquire during more formal education. Importantly, girls were not only socialized through different forms of play, but also taught how to make use of leisure as a space where their proper genteel femininity could be shown. Young gentlewomen were supposed to develop into persons displaying elegance, docility and politeness through such forms of genteel leisure as music and dance. Philip Fithian, a tutor of the children of one of the most wealthy Virginian planter John Carter, characterised two of his pupils in terms of exactly these talents:

Miss Priscilla [ ...] dances finely, plays well key'd Instruments, and is upon the whole in the first Class of the female Sex. Nancy the Second, is [...] only beginning to play the Guitar, she understands the Notes well, \& is a graceful Dancer ${ }^{19}$.

Most children from the gentry families were educated at home, but even when they were sent to school, the expectations of their parents concerned education in polite manners and activities more than in anything else. The Virginia Gazette published numerous advertisements of schools for young gentlewomen. In an advertisement published in 1772, E. Armston informed the public that she would run a school at Point Pleasant in the borough of Norfolk. The announcement boasted about the range of the educational opportunities the school would offer:

....at which School is taught Petit Point in Flowers, Fruit, Landscapes, and Sculptures, Nuns Work, Embroidery in Silk, Gold, Silver, Pearls, or embossed, Shading of all Kinds, in the various Works in Vogue, Dresden Point Work, Lace Ditto, Catgut in different Modes, flourishing Muslin, after the newest Taste, and Most

18 Ibidem.

19 P. V. Fithian, Journal \& Letters of Philip Vickers Fithian, 1773-1774: Plantation Tutor of the Old Dominion, ed. H. D. Farish, Charlottesville, VA 1968 (hereafter cited as PVF), pp. 48-50. 
elegant Pattern, Waxwork in Figure, Fruit, or Flowers, Shell Ditto, or grotesque, Painting in Water Colours and Mezzotinto; also the Art of taking Foliage, with several other Embellishments necessary for the Amusement of Persons of Fortune who have Taste .... Reading will be her peculiar Care. Writing and Arithmetick will be taught by a Master properly qualified, and, if desired, will engage Proficients in Music and Dancing ${ }^{20}$.

As one may note, Mrs. Armston proposed a wide range of subjects connected with domestic work, the purpose of which was rather to keep young women occupied with useful and mildly entertaining activities than to be productive. The education at her school was also to develop the students' taste and aesthetic awareness. Reading, writing and arithmetic came last. First of all, women were supposed to be acquainted with the latest fashion models and emphasis was laid on the ability to demonstrate good taste in appearance and behaviour. In her advertisement, the headmistress answered the demands imposed on young ladies by the necessity to participate in both domestic and social life of the gentry.

The school offered lessons in dancing only as a secondary subject. This was due to the fact that learning to dance was an essential part of elite youth home education, especially requisite for women. Virginians were convinced that dance was an important mode of social interaction. Gentry children received schooling in dance from their early years. In the 1770s, it was customary to hold dancing lessons in rotation at neighbouring plantations. Young students were learning to dance and spending time together, supervised by their parents, and such occasions often resulted in larger public gatherings and led to many other forms of entertainment. The popularity of dancing schools offers evidence how much attention great landowners paid to the education of young people in leisure activities, often at the expense of formal schooling ${ }^{21}$.

Young members of the elite, the future generations of plantation masters and public leaders, were not only taught the movements for fashionable types of dance and familiarized with the formal rituals of the ball. The instruction was extended to the rules of genteel conduct and manners appropriate for formal social situations. In a generally pleasurable and convivial atmosphere, dancing lessons taught punctuality, discipline, precision, responsibility and diligence. Through dancing, young members of the elite, men and women, received training in politeness, propriety, attention to detail and order. Dance was not just a form

\footnotetext{
20 VG (Purdie \& Dixon), February 20, 1772.

21 J. R. Barden, "Innocent and Necessary": Music and Dancing in the Life of Robert Carter of Nominy Hall, 1728-1804, M. A. Thesis, Dept. of History, The College of William and Mary, 1983, pp. 25-26, 35; For Fithian's references to dancing schools see $P V F$, pp. 19, 21, 24, 26-27, $32-34,50-53,66,75,88,111-112 ; 123-125,142,156,178,202$. Dancing was also part of domestic entertainment: Fithian noted one day that in the evening "John the waiting Man play'd, $\&$ the young Ladies spent the evening merrily in dancing," $P V F$, p. 178.
} 
of entertainment, but a practice in self-control and of acceptance of authority. The dance was expected to be "elegant" and "beautiful" as dancers, especially women, being carefully scrutinized by the genteel audience, were aware that they participated in a public display of individual grace and dexterity, testifying to their gentility. The values of the Virginia gentry were expressed not only through the clothing or the language used, but also through the body and its movements ${ }^{22}$.

The most magnificent spectacles of genteel opulence and refinement were balls, held regularly during the "Publick Times" in Williamsburg and county courts sessions in provincial towns, and as events accompanying official holidays and celebrations. The Virginia elite believed that balls and other forms of entertainment combining dance and music served important educating and edifying functions. In a characteristic manner, Alexander Hamilton described balls as "innocent amusements, for the most part so agreeable and entertaining to the young and gay, and indeed, in the opinion of moderate people, so conducive to the improvement of politeness, good manners, and humanity" 23 .

Although dancing at balls was the chief diversion, it was only an element in a complex structure of formal entertainment, prepared with great accuracy, most often by professionals such as dancing instructors, theatre owners or ordinary keepers (an ordinary was a colonial inn). Extraordinary attention to detail and regard for respectability demonstrate how recreational practices were used for constructing a genteel social environment ${ }^{24}$. The balls communicated to the

22 Compare Fithian's descriptions of dancing in Virginia, PVF, pp. 33-34, 50-53.

23 A. Hamilton, Gentleman's Progress: The Itinerarium of Dr. Alexander Hamilton, 1744, ed. C. Bridenbaugh, Chapel Hill, NC 1948, p. 23; compare also the descriptions of W. Black, "Diary, May 17 - June 15, 1744," in Claiborne Family Papers, Virginia Historical Society. Colonial balls are analysed by C. A. Kierner, in "Genteel Balls and Republican Parades..." and discussed by Rozbicki, op. cit., 151-152, 170. Sometimes observers criticized balls for not coming up to the expected standards. For example, Mrs Browne, travelling with the English army in Virginia, attended a ball in Fredericksburg, where she condemned the fact that the "Ladys danced without Stays or Hoops, and it ended with a jig from each Lady," "With Braddock's Army: Mrs. Browne's Diary in Virginia and Maryland," Virginia Magazine of History and Biography, vol. 32 (1924), p. 319.

${ }^{24}$ For balls and dances in Williamsburg advertised in the Virginia Gazette, see, VG, Feb. 25, 1737, April 4, 1737, Oct. 7, 1737, Oct. 21, 1737, March 24, 1738, March 31, 1738, Sept. 11, 1746, April 4, 1751, Oct. 24, 1751, Feb. 2, 1752, March 5, 1752, Nov. 17, 1752, VG (Purdie \& Dixon), June 6, 1766, May 25, 1769, Oct. 26, 1769, Dec. 14, 1769, VG (Rind), Dec. 14, 1769, VG (P\&D), Dec. 28, 1769, Oct. 31, 1771, $V G(R)$, Oct. 31, 1771, $V G(P \& D)$, March 19, 1772, Oct. 29, 1772, $V G(R)$, Oct. 29, 1772, VG (P\&D), Dec. 29, 1774, VG (Pinkney), Dec. 29, 1774, VG (Dixon), Jan. 21, 1775, VG (Purdie), Nov. 21, 1777, VG (Dixon), Feb. 19, 1780. For balls organised on official see $V G(P \& D)$, May 26, 1774, $V G(R)$, May 26, 1774, $V G(P \& D)$, Oct. 29, 1767, Oct. 28, 1773, June 3, 1770, Apr. 19, 1770, Oct. 29, 1772, VG (R), Oct. 29, 1772, June 7, 1770, VG, Nov. 5, 1736, Jan. 21, 1737, Nov. 2, 1737, Nov. 2, 1739, Nov. 14, 1755, VG (Pinkney), Jan. 19, 1775. Dances and balls in provincial towns: Hanover, $V G(R)$, May 11,1769 , in Fredericksburg, $V G(R)$, Dec. 24, 1767, at King William courthouse, $V G(R)$, Oct. 27, 1768, at Sussex courthouse, 
world that the gentry was a unified, integrated group, free of animosity and conflicts, embracing the patriarchal model of society ${ }^{25}$. Ladies, making a splendid appearance, displayed themselves for public appreciation at balls, played central roles in social interactions and ritually expressed the ideals of femininity. The values of propriety, modesty and elegance were symbolised by the regularity and decorum of minuets, cotillions and other social dances, in which groups of dancers rhythmically performed the same movements. Philip Fithian, impressed by the grace and elegance of the dancers at a ball at Squire Lee's house, wrote down in his diary that "[t]he Ladies were Dressed Gay, and splendid, \& when dancing, their Silks \& Brocades rustled and trailed behind them!"26. By such spectacles the gentry assured themselves and the observers that as a group they lived up to the standards of gentility, and, consequently, deserved their privileged status and the right to rule.

For women, balls and other occasions for dancing provided infrequent chances to communicate their personal characteristics to a larger audience. It was a common assumption that the manner of dancing mirrored one's personality. Balls and formal dances were excellent occasions for courting, when, under adult supervision, young people could not only get acquainted with a potential marriage partner, but could also learn more about his or her character through conversation and dancing. Young men and women were able to review the market of candidates for marriage, and dancing skills served as an important measure of one's suitability. Women constituted leisure for men and men had the power to sexualize social contexts and to objectify women and their bodies. Young girls in particular were expected to use balls to show to the public that they qualified as gentlewomen and candidates for wives. Philip Fithian, present at a ball at Hobbs's Hole in August 1774, filled his diary with a list containing attributes of the young ladies present at the event, focusing on the dancing skills, social graces, and costume. He praised Miss Aphia Fantleroy, "the best Dancer of the whole absolutely - And the finest Girl - Her head tho' was powdered white as Snow, \& crap'd in the newest Taste - She [was] the Copy of the goddess of Modesty - Very handsome; she seemed to be loved by all her Acquaintances, and admir'd by every Stranger." Occasionally, dancing seems to have had a competitive character, also among women, who contested with each other to appear most

$V G(P \& D)$, March 17, 1768, Feb. 22, 1770, in Charles City County, $V G(R)$, May 12, 1774, in Great Bridge, $V G(P \& D)$, June 13, 1766, in Hampton, $V G(P \& D)$, June 13, 1766, in Newcastle, Aug. 28, 1746, in Newtown, $V G(P \& D)$, July 4, 1766, in Norfolk, $V G$, July 31, 1746, $V G(P \& D)$, June 6, 1766, $V G(P \& D)$, May 19, 1774, $V G$, May 19, 1774.

25 For such descriptions of balls see $P V F$, pp. 120, 161, 178; [Lucinda Lee], Journal of a Young Lady of Virginia, 1782, Baltimore 1871, Oct. 15, 16, 17, 1782, pp. 33-35; Oct. 23, 24, 1782, pp. 39-40; Nov. 9, 1782, p. 51.

26 PVF, pp. 56-57. 
desirable, of course, trying not to break the social conventions in the process. William Black used the phrase "Dancing Match" to describe what he observed during one of the balls he attended ${ }^{27}$.

Dancing was a form of leisure and a test of how much gentry girls acquired the required feminine identity, expressed through their refinement and social skills. However, the dancing floor could also be used for negotiation of one's gender identity and expression of individuality. This was possible because dance in Virginia was also supposed to be an expression of energy, "great spirit," and enthusiasm. Many women preferred more unstructured and casual forms of dance, which allowed greater improvisation and easier expression of one's feelings and a show of sexuality, providing them also with limited liberation and a strong sense of satisfaction. The pleasures of the balls were of a more physical then intellectual nature. Philip Fithian noticed after one ball, when he got to bed in the early morning "after a day spent in constant Violent Exercise, $\&$ drinking an unusual Quantity of Liquor," "with Fatigue, Heat, Liquor, Noise, Want of sleep, and the exertion of [...] Animal spirits." Although the genteel discourse of leisure dominated during the formal celebrations of this kind and required women to be the living embodiments of the virtues of gentility, other, alternative discourses of pleasure also be identified in such rituals. The lively, more physical and less controlled forms of dancing were possibly more closely related to the circumstances of the dynamic, competitive and often unpredictable life of the Virginia gentry, and gave some women a temporary reprieve from following the strict codes of femininity ${ }^{28}$.

The evoked examples presented above show that in eighteenth-century Virginia leisure practices worked as powerful mechanisms in gender construction, representing the dominant ideals of masculinity and femininity. Play was used for the individual's enculturation in genteel values, and showed young people the roles expected of them in the future. Leisure activities supervised by adults were teaching socially appropriate life goals. Leisure rituals not only provided opportunities for male-female contact but also symbolically conveyed gender models. The visible differences between male and female recreations worked as mechanisms of male hegemony. Women from the gentry class were obliged to maintain an appearance of leisure, but their leisure was repressed by restrictions

27 See Robert Bolling Woos Anne Miller: Love and Courtship in Colonial Virginia, 1760, ed. J. A. L. Lemay, Charlottesville, VA 1990, esp. pp. 53-55, 66-7, for first-hand descriptions of the courting rituals during colonial balls; $P V F$, pp. 154-156; Black, op. cit. Rhys Isaac offers a similar interpretation of dancing in colonial Virginia in The Transformation of Virginia, 1740 1790, Chapel Hill, NC 1982, pp. 80-87.

$28 P V F$, p. 88 and pp. 154-156. Fithian's observations were shared by Nicholas Cresswell, another visitor to the colony in the 1770s, The Journal of Nicholas Cresswell, 1774-1777, Port Washington, N.Y., pp. 52-3. 
on where they were permitted to go and what they were allowed to do in their free time. They were treated as symbolic objects whose cultural performance could endorse - or compromise - male pretensions to a superior status. One could say they were locked up in the culture of leisure. However, despite the limitations, gentlewomen also managed to use the sphere of leisure to express their personality and individuality, negotiating both the boundaries of gender and the strength of patriarchal relations.

\section{The Leisure Pursuits of Gentlewomen in Colonial Virginia: Gender Construction and Male Domination}

Artykuł przedstawia sposoby spędzania wolnego czasu przez szlachtę w Wirginii, osiemnastowiecznej brytyjskiej kolonii w Ameryce Północnej. Koncentrując się na rozrywkach kobiet z kolonialnej elity, autor omawia znaczenie takich form zabawy, jak bale i uroczyste przyjęcia, które były ogromnie ważne w procesie kształtowania się tożsamości szlachty wirgińskiej. Towarzyszące rozrywkom wyrafinowane zachowania i ostentacyjna konsumpcja miały być dowodem na szlachectwo elity, co z kolei miało jej dawać prawo do władzy $\mathrm{w}$ kolonii. Kobietom $\mathrm{z}$ elity zalecano takie formy spędzania wolnego czasu, poprzez które mogłyby one wykazać cechy przypisane modelowi kobiecości: grację, skromność, ogładę i elegancję. Takie cechy kobiecości symbolicznie wyrażane były na przykład przez taniec. Rozrywki szlacheckie w wyrazisty sposób nie tylko ukazywały różnice w społecznej pozycji mężczyzn i kobiet, ale również podkreślały społeczną dominację męskiej części elity.

Key words: colonial Virginia, leisure, women

Słowa kluczowe: kolonialna Wirginia, czas wolny, kobiety 